\title{
The Pneumocystis life cycle
}

\author{
Cécile-Marie Aliouat-Denis ${ }^{1,2}$, Anna Martinez ${ }^{1,2}$, El Moukhtar Aliouat ${ }^{1,2}$, Muriel Pottier ${ }^{1}$, \\ Nausicaa Gantois ${ }^{2}$, Eduardo Dei-Cas ${ }^{2,3 /+}$

\begin{abstract}
${ }^{3}$ Department of Parasitology-Mycology, Faculty of Medicine, University Hospital Center ${ }^{1}$ Department of Parasitology, Faculty of
\end{abstract} \\ Biological and Pharmaceutical Sciences, University of Lille Nord de France, 3 rue du Pr. Laguesse, BP83, 59006 Lille, France ${ }^{2}$ EA3609, \\ IFR142, Pasteur Institute of Lille, Lille, France
}

First recognised as "schizonts" of Trypanosoma cruzi, Pneumocystis organisms are now considered as part of an early-diverging lineage of Ascomycetes. As no robust long-term culture model is available, most data on the Pneumocystis cell cycle have stemmed from ultrastructural images of infected mammalian lungs. Although most fungi developing in animals do not complete a sexual cycle in vivo, Pneumocystis species constitute one of a few exceptions. Recently, the molecular identification of several key players in the fungal mating pathway has provided further evidence for the existence of conjugation and meiosis in Pneumocystis organisms. Dynamic follow-up of stage-tostage transition as well as studies of stage-specific proteins and/or genes would provide a better understanding of the still hypothetical Pneumocystis life cycle. Although difficult to achieve, stage purification seems a reasonable way forward in the absence of efficient culture systems. This mini-review provides a comprehensive overview of the historical milestones leading to the current knowledge available on the Pneumocystis life cycle.

Key words: Pneumocystis - cell sorting - life cycle stages - ploidy - mating

\section{History of research on the Pneumocystis life cycle}

The history of the Pneumocystis genus, which was reviewed recently (Calderón-Sandubete et al. 2002, Redhead et al. 2006), begins in Brazil, where Carlos Chagas (1879-1934) first discovered Pneumocystis cystic forms in 1909 while he was assessing malaria prophylaxis measures in the state of Minas Gerais (Delaporte 2003). Chagas observed such forms in the lungs of guinea pigs inoculated with the blood of two children with trypanosomiasis and in the lungs of the first human case of acute American trypanosomiasis (Chagas 1911, Delaporte 2003). He wrongly thought that such forms revealed the occurrence of a schizogonic process in Trypanosoma cruzi, and for this reason he proposed to name the genus Schizotrypanum (Chagas 1909). In 1910, Antonio Carini (1872-1950), while director of the São Paulo Pasteur Institute (Brazil), found similar cysts in the lungs of rats (Rattus norvegicus) infected by Trypanosoma lewisi (Carini 1910). He sent tissue samples to Alphonse Laveran at the Pasteur Institute of Paris, where two Laveran's fellows, Mr. and Mrs. Delanoë, observed similar pulmonary cysts in sewer rats ( $R$. norvegicus) from Paris that were not infected by trypanosomes. They concluded that the pulmonary cystic bodies reported by Chagas and Carini were indeed a new biological entity unrelated to trypanosomes (Delanoë \& Delanoë

Financial support: ANR-ERA-NET "Pneumocystis" PathoGenoMics Program, ANR-06-PATHO-009-01, French Ministry of Research and Education (EA3609, University of Lille 2, Quadrennial Contract, 2006-2009)

+ Corresponding author: eduardo.dei-cas@pasteur-lille.fr

Received 24 July 2008

Accepted 10 March 2009
1912, Hughes 1987, Calderón-Sandubete et al. 2002) and they speculated about its potential relationship with coccidian protozoa. They suggested naming it Pneumocystis carinii: "Pneumo" in relation with lung tropism, "cystis" because of its typical shape and "carinii" to honour Dr. Antonio Carini (Delanoë \& Delanoë 1912). Delanoë and Delanoë (1912) only mentioned cystic forms and no reference was made to non-cystic forms of Pneumocystis for a long time. In 1942, van der Meer and Brug published the first light microscopy photographs of Pneumocystis trophic and cystic forms in human beings [accompanied by concise and aesthetic drawings' reproduced in the book by Hughes (1987)].

Although many authors (for instance, Jirovec 1964, Kim et al. 1972) suggested hypotheses regarding the Pneumocystis life cycle, the best ones were based on ultrastructural observations (Vavra \& Kucera 1970, Campbell 1972, Vossen et al. 1978, Matsumoto \& Yoshida 1984, Yoshida 1989, Dei-Cas 2000). Thus, a major event in the history of Pneumocystis life cycle research was undoubtedly the finding of synaptonemal complexes in the nucleus of early sporocytes, indicating the occurrence of a meiotic division, i.e., of a sexual cycle (Matsumoto \& Yoshida 1984). Thus, these authors proposed an original Pneumocystis life cycle hypothesis with a high heuristic value (Dei-Cas et al. 2004, 2006, Aliouat-Denis et al. 2008) that associates both sexual and asexual modes of multiplication (Matsumoto \& Yoshida 1984, Yoshida 1989).

The fungal nature of Pneumocystis was suggested by Vavra and Kucera (1970) on the basis of ultrastructural studies. It was further strengthened by Ruffolo (1994) when he proposed to rename the Pneumocystis stages according to fungal terminology. The controversy about the fungal versus protozoan nature of Pneumocystis remained until the end of the 1980s when the first definite proof of its fungal nature was provided (Edman et al. 
1988, Stringer et al. 1989). The genus Pneumocystis has its own designated Pneumocystidaceae family (Eriksson 1994), which belongs to the subphylum "Taphrinomycotina" sensu Eriksson and Winka 1997 or "Archiascomycetes" sensu Nishida and Sugiyama 1994. The monophyletic taxon "Taphrinomycotina" includes ecologically and morphologically diverse fungi that diverged early from Ascomycota (Sugiyama et al. 2006).

\section{Pneumocystis life cycle stages}

Hypotheses on the Pneumocystis life cycle stem from transmission electron microscopy (TEM) micrographs and three-dimensional reconstructions of Pneumocystis organisms as well as recent molecular data. All known life cycle stages of Pneumocystis have been found in the lungs of infected mammals and, more rarely, in extrapulmonary locations primarily in severely immunocompromised hosts ( $\mathrm{Ng}$ et al. 1997, Anuradha \& Sinha 2007). Several authors have drawn slightly different hypothetical life cycle schemes in which both sexual and asexual reproduction alternate in vivo (Yoshida et al. 1984, Yoshida 1989, Cushion 2004, Dei-Cas et al. 2004, De Souza \& Benchimol 2005, Thomas \& Limper 2007, Aliouat-Denis et al. 2008). Lack of robust, long-term culture has prevented detailed dynamic follow-up of differentiation of the Pneumocystis life cycle stages. Thus, it was formerly impossible to test hypotheses on the life cycle.

Trophic forms, sporocytes and mature cysts are usually considered as the three main morphological forms involved in the Pneumocystis life cycle. Trophic forms are the most abundant of all Pneumocystis life cycle stages, representing $90-95 \%$ of the total population in the lungs of hosts with pneumocystosis. These vegetative forms appear as mononuclear, 2-8 $\mu \mathrm{m}$ in diameter, mostly haploid eukaryotic cells (Cornillot et al. 2002, Dei-Cas et al. 2004) presenting a thin cell wall consisting of an electron-dense single layer (Table). Ameboid in shape, trophic forms display cytoplasmic projections known as filopodia, which allow them to attach closely to type I pneumocytes (Aliouat-Denis et al. 2008). Ultrastructural studies as well as the re-

TABLE

Life cycle parasite stages of Pneumocystis organisms

\begin{tabular}{lcccccc}
\hline \multicolumn{5}{c}{ A: Light microscopy } \\
\hline & Trophic form & Early sporocyte & Intermediate sporocyte & Late sporocyte & Cyst \\
\hline TBO & - & - & + & + & + & + \\
Giemsa & + & + & + & + & + \\
\hline
\end{tabular}

TBO: Toluidine Blue O; -: unstained; +: stained (modified from Dei-Cas et al. 2004).

B: Transmission electron microscopy

\begin{tabular}{|c|c|c|c|c|c|c|}
\hline & Trophic form & $\begin{array}{c}\text { Early } \\
\text { sporocyte }\end{array}$ & $\begin{array}{l}\text { Intermediate } \\
\text { sporocyte }\end{array}$ & $\begin{array}{c}\text { Late } \\
\text { sporocyte }\end{array}$ & Cyst & Spore \\
\hline Shape & Irregular & Ovoid & Ovoid & Ovoid & Ovoid & $\begin{array}{c}\text { Ovoid, } \\
\text { amoeboid or } \\
\text { crescent-shaped }\end{array}$ \\
\hline Diameter $(\mu \mathrm{m})$ & $2-8$ & $3.5-4.5$ & $4-6$ & $4-6$ & $4-7$ & $1-2$ \\
\hline Number of nucleus & 1 & 1 & $2-8$ & 8 & $8^{a}$ & 1 \\
\hline Ploidy $^{b}$ & $\mathrm{n}$ & $2 \mathrm{n}^{c}$ & $\mathrm{n}$ & $\mathrm{n}$ & $\mathrm{N}^{a}$ & $\mathrm{n}$ \\
\hline $\begin{array}{l}\text { Synaptonemal } \\
\text { complexes }\end{array}$ & No & Yes & No & No & No & No \\
\hline $\mathrm{NAO}^{d}$ & No & No & Yes & Yes & No & No \\
\hline Nuclear spindle & No & Yes & Yes & No & No & No \\
\hline Mitochondrion $^{e}$ & $\begin{array}{c}\text { Elongated, } \\
\text { little ramified }\end{array}$ & Ramified & Dendritic & Split & Ovoid, dense & Ovoid, dense \\
\hline $\begin{array}{l}\text { Cell wall } \\
\text { (diameter in } \mathrm{nm} \text { ) }\end{array}$ & $\begin{array}{l}\text { Electron-dense } \\
\text { layer }(20-25 \mathrm{~nm})\end{array}$ & $\begin{array}{l}\text { Electron-dense } \\
\text { layer }(35-45 \mathrm{~nm})\end{array}$ & $\begin{array}{c}\text { Electron-dense + } \\
\text { inner electron- } \\
\text { lucent layers } \\
(80-100 \mathrm{~nm})\end{array}$ & $\begin{array}{c}\text { Electron-dense + } \\
\text { inner electron- } \\
\text { lucent layers } \\
(80-120 \mathrm{~nm})\end{array}$ & $\begin{array}{l}\text { Electron-dense }+ \\
\text { electron-lucent } \\
\text { layers }(80-120 \mathrm{~nm})\end{array}$ & $\begin{array}{l}\text { Electron - } \\
\text { dense layer } \\
(20-23 \mathrm{~nm})\end{array}$ \\
\hline Filopodia & numerous & poorly developed & scarce & scarce & scarce & none \\
\hline
\end{tabular}

$a$ : one nucleus in each one of the eight spores; $b$ : hypothetical ploidy considering the report by Matsumoto \& Yoshida (1984) and our own observations (modified from Dei-Cas et al. 2004); $c$ : diploid early sporocyte results probably from conjugation of haploid trophic forms; $d$ : nuclear-associated organelles; $e$ : these terms refer to detailed computer-aided 3D-ultrastructural reconstruction of Pneumocystis mitochondrion as described by Palluault et al. (1991a, b). 
cent discovery of the Ste3 pheromone receptor gene and the Ste2-like homologue within the Pneumocystis genome suggest the existence of mating types and the probable conjugation of Pneumocystis trophic forms in vivo (Itatani 1996, Smulian et al. 2001, Cushion 2004). Following the fusion of mating types, a round, thin-walled, mononuclear and probably diploid early sporocyte is produced and shortly thereafter enters a meiotic division process. Ultrastructural images of a synaptonemal complex reported within the nucleus of early sporocytes support the occurrence of meiosis in Pneumocystis (Matsumoto \& Yoshida 1984, Peters et al. 2001). Meiosis is followed by an additional mitotic replication resulting in eight nuclei in the late sporo- cyte stage (Table, Fig. 1). While nuclear division and organelle segregation proceed, an electron-lucent layer appears between the electron-dense layer and the plasma membrane of the intermediate sporocyte. It further thickens at the late sporocyte stage to finally produce a thick-walled mature cyst that measures 4-7 $\mu \mathrm{m}$ in diameter (Dei-Cas et al. 2004). Its surface is rather smooth, with few filopodia. In the mature cyst, eight individual spores are clearly delineated and are protected by a cell wall that appears as thick as the cell wall of the trophic form (Table). Spores consist of a single nucleus and a fairly dense cytoplasm with a rounded, well-defined electron-dense mitochondrion, a well-developed rough endoplasmic reticulum and numerous ribosomes

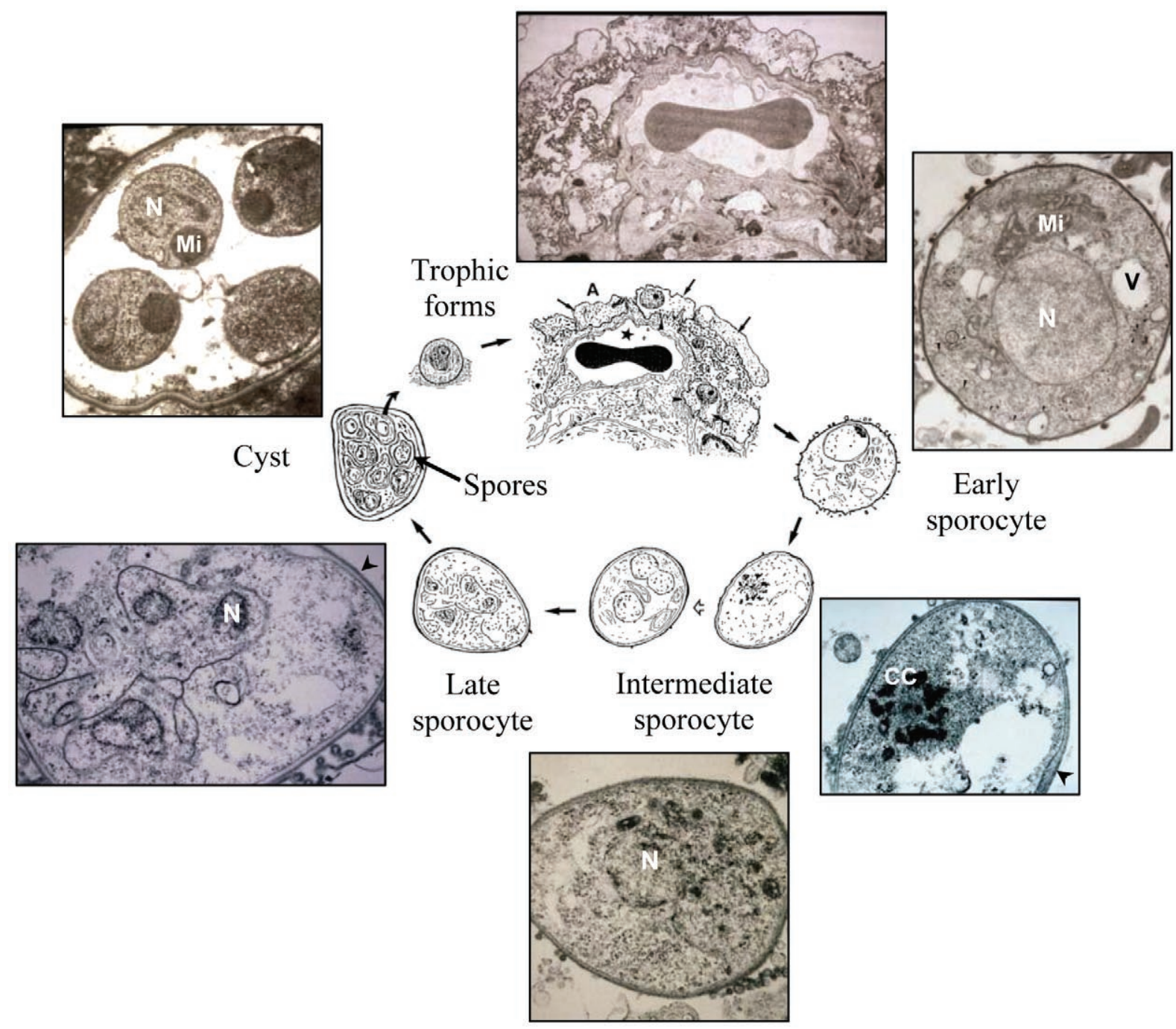

Fig. 1: a hypothetical Pneumocystis life cycle illustrated by transmission electron micrographs and corresponding interpretation drawings of organisms developing in mammalian lungs. Mononuclear thin-walled trophic forms (small arrows) are attached to type 1 epithelial alveolar cell that is close to a capillary vessel (star). Following conjugation (Itatani 1996), trophic forms would evolve into thin-walled round early sporocyte in which synaptonemal complex has been reported (Matsumoto \& Yoshida 1984, Peter et al. 2001). While electron-lucent layer (arrowhead) develops in intermediate sporocytes, meiotic nuclear division proceeds. An additional mitotic replication leads to a thick-walled late sporocyte (arrowhead) containing eight nuclei. In the mature cyst, the eight spores are fully delineated. These forms are able to leave the cyst and subsequently attach to type I alveolar cells. A: alveolar space; CC: condensed chromosomes and spindle microtubules; N: nucleus; Mi: mitochondrion; V: vacuole. Arrowheads indicate thick cell wall. 
(Dei-Cas et al. 2004). Morphologically, spores can be spherical, banana-shaped or irregular. Once fully matured, they leave the cyst, probably through a foramenlike structure, to give rise to eight free haploid trophic forms (Yoshida 1989, Itatani 1994).

Transmission has been shown to occur from individual to individual by the airborne route (Walzer et al. 1977, Hughes 1982), although the infective form has not been elucidated. Although Pneumocystis DNA has been detected in ambient air, no environmental form has thus far been isolated (Wakefield 1996). The thick-walled mature cyst is certainly best equipped to retain infectivity during transient host-to-host air travel. Furthermore, detection of mature cysts in the bronchial lumen by TEM suggests that they may reach the external environment and be transmitted to other hosts (Dei-Cas 2000).

\section{Exploring Pneumocystis growth}

The pathogenicity of Pneumocystis appears clearly linked to both the proliferation capacity of these fungi and the detrimental inflammatory response elicited by the host (Lebron et al. 2003, Thomas \& Limper 2007). However, data about Pneumocystis multiplication mechanisms are scarce or controversial. As indicated above, in the infected lungs of patients or immunosuppressed laboratory animals, trophic forms represent $90-95 \%$ of the total parasite population. Mainly for this reason, it is currently thought that Pneumocystis proliferation results from active binary fission of trophic forms (Cushion 2004, De Souza \& Benchimol 2005). Although few ultrastructural micrographs of binary fission have been reported (Richardson et al. 1989), 15 years of studying Pneumocystis ultrastructure led us to hypothesise that nuclear division would only occur within the cystic forms (Aliouat et al. 1999, Dei-Cas et al. 2004). In order to test this hypothesis, Aliouat et al. (1999) explored Pneumocystis growth in cultures of epithelial alveolar cells (Aliouat 1995, European Concerted Action 1996). Trophic forms, cystic forms containing developing or developed spores ("filled" cysts) and empty cysts were carefully quantified on dry smears stained with either Toluidine Blue O or RAL555, a Giemsa-like stain. The staining features of each parasite stage are detailed in Table. Pneumocystis growth kinetics was determined by plotting the parasite population' on a semilogarithmic curve, and doubling time (DT) was calculated at the exponential phase as follows: DT $=\ln 2 / \mu$, where $\mu$ represents the specific growth rate (i.e., slope of the curve). An increase in the number of filled or empty cysts was observed, showing that cysts contributed to fungal growth. Indeed, the increase in the frequency of empty cysts indicated that the trophic forms were produced from filled cysts; reciprocally, the increase in the number of filled cysts indicated that the trophic forms produced filled cysts. Now, did the trophic forms develop further binary fission? If the trophic forms did not divide, each time one filled cyst produced an empty cyst, eight trophic forms would be released. Therefore, the empty cyst versus trophic form curve should be a straight line with a slope equal to eight. Alternatively, if the trophic forms did divide, the slope should obvi- ously be greater than eight. Interestingly, in cultures of $P$. carinii with epithelial alveolar cells, the slope was actually 8.08 , suggesting that one trophic form gives rise to only eight trophic forms via cyst production and that no other replication mechanism occurred (Aliouat et al. 1999). This result strengthens the hypothesis proposed by Schmatz et al. $(1990,1991)$ that the cyst stage is required for proliferation of trophic forms.

\section{Mating}

Pneumocystis species as well as biotrophic fungi of plants (O'Connell \& Panstruga 2006) usually develop sexual reproduction within their host (Cushion et al. 2007). In contrast, most fungi developing in animals do not appear to complete a sexual cycle (Sexton \& Howlett 2006). Some exceptions to this rule may nevertheless be noted. Aspergillus nidulans is sometimes able to sexually reproduce in vivo in human as well as in animal tissues, thus producing cleistothecia and Hülle cells (Doby \& Kombila-Favry 1978, Dei-Cas \& Vernes 1986, Mitchell et al. 1987). More recently, the existence of an anamorph state of Candida lusitaniae was questioned since $100 \%$ of 76 clinical isolates were able to mate and undergo meiosis once put in contact with a sexually compatible strain (François et al. 2001). This result indicates that $C$. lusitaniae still uses meiosis as a source of genetic variability; this could explain the higher propensity of C. lusitaniae to acquire antifungal resistance (François et al. 2001).

Pneumocystis species also present exceptions to the rule. TEM micrographs as well as recently identified mating genes located in the Pnemocystis genome (The Pneumocystis Genome Project available from http://pgp. cchmc.org/) provide evidence for the existence of conjugation between trophic forms. Itatani (1996) reported the occurrence of binucleated trophic forms in the lungs of infected rats. The existence of a cytoplasmic isthmus and the asymmetrical position of both nuclei on one side indicate that both trophic forms probably fused at one definitive site and that one nucleus migrated toward the other. Moreover, the close apposition and orientation of spindle pole bodies associated with each nucleus are strongly suggestive of conjugation (Itatani 1996).

More recently, fungal homologues involved in pheromone/mating signalling cascades have been identified in the Pneumocystis genome, strengthening the hypothesis of the existence of a sexual cycle in Pneumocystis. Generally, the mating process is initiated after mutual secretion of pheromones by fungal cells of opposite mating types. Pheromone secretion is also stimulated by environmental stress like nutrition deprivation ( $\mathrm{Li}$ et al. 2007). Pheromones recognise a heterotrimeric G-coupled transmembrane receptor located at the cell surface of the opposite mating type. In turn, the mitogen-activated protein kinase (MAPK) signal transduction cascade is activated ( $\mathrm{Li}$ et al. 2007). Once activated, MAPK controls many cell effectors that halt the mitotic cell cycle, initiate transcription of genes involved in mating and eventually allow the fusion of both cells (Harigaya \& Yamamoto 2007). 
Using degenerate PCR and library screening, Thomas et al. (1998) identified a gene encoding for a MAPK in $P$. carinii that is homologous to other fungal MAPKs involved in differentiation and proliferation. A few years later, heterologous expression of $P$. carinii MAPK (PCM) was shown to restore pheromone signalling in Saccharomyces cerevisiae Fus3/Kss1 double mutants (Vohra et al. 2003b). PCM was mainly expressed in $P$. carinii trophic forms (Vohra et al. 2003b). PCM was then reported to phosphorylate the $P$. carinii homologue of Schizosaccharomyces pombe Stel1 (Ste12 in S. cerevisiae), which encodes a transcriptional factor necessary for the pheromone-induced expression of genes required for mating (Vohra et al. 2003a). Once conjugation has occurred, activation of Stell indirectly turns on Mei2, which plays pivotal roles in both the induction and the progression of meiosis (Harigaya \& Yamamoto 2007). PCMei2, a homologue of $S$. pombe Mei2, has recently been identified using the Pneumocystis Genome Project database (Burgess et al. 2008). The same research group also identified another kinase, PCRanl, as an $S$. pombe Ranl (Pat1) homologue. Ranl is known to directly phosphorylate and inhibit the activity of Mei2. Indeed, Burgess et al. (2008) have shown phosphorylation of PcMei2 by PCRanl in vitro as well as higher expression of PCRanl in cystic forms, thus suggesting that meiosis is inhibited in this life cycle stage. Moreover, both genes exhibited functional activity in meiotic control when expressed in $S$. pombe.

P. carinii Ste3, an a-factor pheromone receptor homologue, was identified from an expressed sequence tag (EST) database that was created as part of the Pneumocystis Genome Project (Smulian et al. 2001). It further confirms the existence of a sexual replication cycle in vivo (Smulian et al. 2001). This G-protein-coupled receptor was later reported to be exclusively expressed in a sub-population of trophic forms (Vohra et al. 2004). This finding is consistent with the expression pattern of pheromone receptors in other fungi. So far, no ligand has been identified for this receptor. Genes encoding functional elements of the pheromone response signal transduction cascade, like Ste12 and Ste20 orthologues, are clustered around the Pneumocystis Ste3 gene (Smulian et al. 2001). P. carinii Ste20 (PCSTE20) was later shown to be expressed following adherence of the fungus to extracellular matrix components and lung epithelial cells (Kottom et al. 2003). Heterologous expression of PCSTE20 conferred pseudohyphal growth and also revealed the gene to be functional in mating signalling pathways in $S$. cerevisae mutant strains (Kottom et al. 2003). Additional orthologues of fungal genes associated with either the mating/sexual mode of replication or stress/nutritional deprivation were identified in the $P$. carinii EST database, thus pointing to these conditions as triggers of Pneumocystis mating (Cushion et al. 2007).

\section{How to investigate the Pneumocystis cell cycle?}

Our aim is to dynamically study, both in vitro and in vivo, the completion of the Pneumocystis life cycle. To reach this aim, several obstacles need to be overcome. First of all, no long term culture system of Pneumocys- tis organisms is available, which prevents any attempt to synchronise fungal growth or stage differentiation in vitro. It is thus difficult to pinpoint the outcome of each life cycle stage. Second, Pneumocystis organisms are fairly small in size and have a tendency to form aggregates that render purification from host cell debris and stage-to-stage separation difficult. A number of authors have tested several methods such as sucrose density centrifugation (Lim et al. 1973), gravity sedimentation (Taylor \& Easmon 1990) or dialysis (Read \& Burns 1991) and Percoll gradient (Chin et al. 1996) in order to enrich for fungal organisms against host cell debris (De Stefano et al. 1994).

Several techniques provide partial stage-to-stage purification of $P$. carinii; they include gravitational fieldflow fractionation (Bories et al. 1992), immunomagnetic sorting (Aliouat-Denis, unpublished observations), sequential filtrations (Durkin et al. 1991, Vohra et al. 2004), elutriation combined with sequential filtrations (De Stefano et al. 1994) and flow cytometry (De Stefano et al. 1992). The last two procedures only provide good enrichment of cystic forms (95-96\%) and their infectivity has not been tested.

High-speed cell sorting was our chosen strategy to purify $P$. carinii organisms from host cell debris and to achieve stage-to-stage separation with high purity (Martinez et al. 2009). A polyclonal antibody produced in our laboratory was used to label the whole $P$. carinii population. A commercially available monoclonal antibody (Monofluo ${ }^{\mathrm{TM}} \mathrm{Kit}$ "Pneumocystis jirovecii (P. carinii)", BioRad) that requires trypsin digestion was used to specifically label cystic forms. The epitope recognised by the monoclonal antibody lies in the electron-lucent layer of rodent and human Pneumocystis sporocytes and mature cysts (Sukura et al. 1994) and does not cross-react with host cell debris or yeasts (Lautenschlager et al. 1996). The experimental protocol was refined in order to avoid $P$. carinii clumps and to reach the best compromise between efficient cyst labelling and preservation of fungus integrity. The cytological and ultrastructural integrity of trypsin-treated $P$. carinii organisms was assessed. Trypsin treatment affected the outer electron-dense layer that was thinner in trypsin-treated trophic forms than in controls, whereas it completely disappeared in cystic forms, directly exposing the electron-lucent middle layer to the external environment. No other ultrastructural alterations were noted. Separation of cyst forms from trophic forms was achieved by flow cytometry with a purity of $99.6 \pm 0.3 \%$ in 27 independent cell sorting experiments (Figs 2-6) (Martinez et al. 2009).

Dexamethasone-treated Lou nu/nu rats were used to monitor the impact of the trypsin treatment, co-immunostaining and sorting steps on $P$. carinii infectivity. Following endotracheal inoculation, sorted $P$. carinii had decreased infectivity but remained infectious to the Nude rats (Martinez et al. 2009).

We are currently following stage-to-stage differentiation of $P$. carinii both in vitro and in vivo. Purified life cycle stage populations are endotracheally inoculated to 

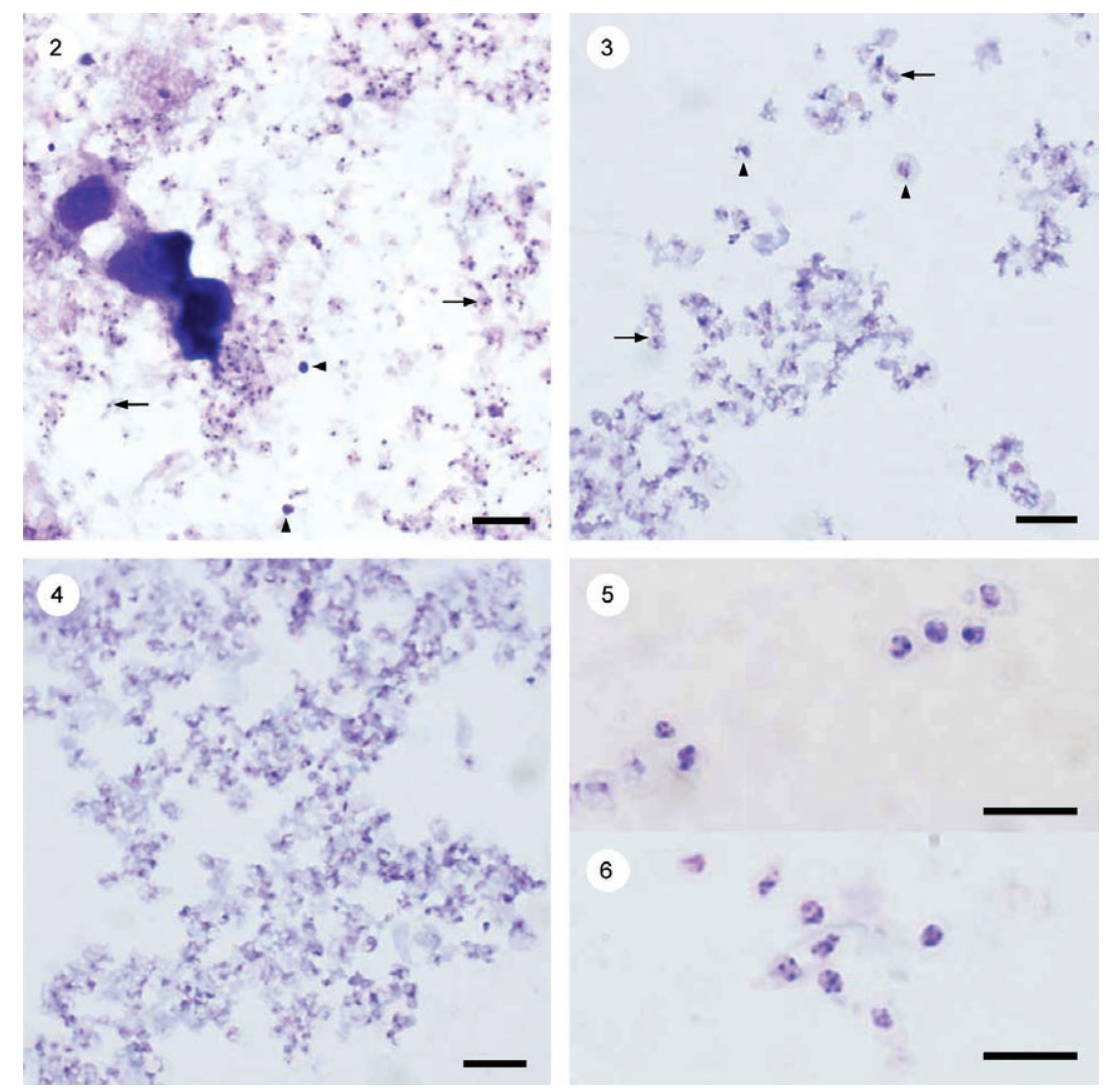

Figs 2-6: purification of Pneumocystis carinii trophic (arrows) and cystic (arrow heads) forms using high speed cell sorting. P. carinii organisms are stained with panoptic RAL-555 stain. Scale bar $=10 \mu \mathrm{m} ; 2$ : $P$. carinii organisms recovered from rat lung tissue before immunostaining and cell sorting. Trophic forms (arrows) and cysts (arrowheads) are clearly visible. Numerous lung cell debris (e.g. dark round bodies) are present. 3: whole population of $P$. carinii life cycle stages after cell sorting. No lung cell debris is visible. 4: purified $P$. carinii trophic forms after cell sorting. 5, 6: purified $P$. carinii cystic forms after cell sorting. Purity reached $99.6 \pm 0,3 \%$ in 27 independent sorting experiments.

Nude rats and the proportions of trophic and cystic forms as well as sporocytes are followed during the course of pneumocystosis. The behaviour of the purified life cycle stages was also studied in vitro both in axenic culture and in co-culture with L2 cells (rat lung epithelial cells, ATCC CCL-149). This approach will allow us to pinpoint the blocking step that prevents the completion of the $P$. carinii life cycle in culture. Ideally, stage-specific genes or proteins as well as genes/proteins involved in stage-to-stage differentiation will be identified by comparing gene expression profiles using microarrays and the 2D gel electrophoresis patterns of purified $P$. carinii trophic or cystic form populations. These transcriptomic and proteomic approaches have already been started as part of an international collaboration network (ANRERA-NET "Pneumocystis" PathoGenoMics Program, ANR-06-PATHO-009-01).

Estimation of the ploidy level of $P$. carinii has already been reported and haploidy has been predicted for most Pneumocytis life cycle forms (Stringer \& Cushion 1998). Fifteen gene-specific DNA probes were hybridised to individual bands on seven karyotype forms produced by pulse-field gel electrophoresis (Cushion 1998). Each probe hybridised to a single band in all electrophoretic karyotypes, suggesting that $P$. carinii f.sp. carinii is mainly haploid. Similarly, quantitative image analysis of Pneumocystis nuclei stained with fluorescent dyes revealed that both trophic forms and spores were haploid (Wyder et al. 1998). Two-dimensional pulse-field gel electrophoresis allowed Cornillot et al. (2002) to identify homologues for at least two chromosomes. These results raised some questions about the ploidy status of the Pneumocystis nucleus. Our preliminary experiments of DNA content measurements in Pneumocystis cystic forms by flow cytometry confirm that each spore contains one copy of DNA content. In contrast, trophic forms would not only be haploid (unpublished observations).

\section{REFERENCES}

Aliouat-Denis CM, Chabé M, Demanche C, Aliouat EM, Viscogliosi E, Guillot J, Delhaes L, Dei-Cas E 2008. Pneumocystis species, coevolution and pathogenic power. Infect Genet Evol 8: 708-726.

Aliouat EM 1995. Etude de l'expression phénotypique de la diversité génique de Pneumocystis carinii: infectivité et spécificité parasitaire, PhD Thesis, Université de Lille 1, France, 152 pp.

Aliouat EM, Dujardin L, Martinez A, Duriez T, Ricard I, Dei-Cas E 
1999. Pneumocystis carinii growth kinetics in culture systems and in hosts: involvement of each life cycle parasite stage. $J E u$ karyot Microbiol 46 (Suppl.): 116S-117S.

Anuradha, Sinha A 2007. Extrapulmonary Pneumocystis carinii infection in an AIDS patient: a case report. Acta Cytol 51: 599-601.

Bories C, Cardot PJ, Abramowski V, Poüs C, Merino-Dugay A, Baron B, Mougeot G 1992. Elution mode of Pneumocystis carinii cysts in gravitational field-flow fractionation. J Chromatogr 579: 143-152.

Burgess JW, Kottom TJ, Limper AH 2008. Pneumocystis carinii exhibits a conserved meiotic control pathway. Infect Immun 76: 417-425.

Calderón-Sandubete EJ, Varela-Aguilar JM, Medrano-Ortega FJ, Nieto-Guerrer V, Respaldiza-Salas N, de la Horra-Padilla C, Dei-Cas E 2002. Historical perspective on Pneumocystis carinii infection. Protist 153: 303-310.

Campbell WG 1972. Ultrastructure of Pneumocystis in human lungs: life cycle of human pneumocystosis. Arch Pathol 93: 312-324.

Carini A 1910. Formas de eschizogonia do Trypanosoma lewisi. Bol Soc Med Cir São Paulo 18: 204.

Chagas C 1909. Nova tripanozomiazaea humana. Mem Inst Oswaldo Cruz 1: 159-218.

Chagas C 1911. Nova entidade morbida do homen: regumo general de estudos etiologicos e clinicos. Mem Inst Oswaldo Cruz 3: 219-275.

Chin K, Merali S, Shaw MM, Bartlett MS, Clarkson AB 1996. Subpopulations of Pneumocystis carinii separated by a Percoll gradient. J Eukaryot Microbiol 43 (Suppl.): 53S.

Cornillot E, Keller B, Cushion MT, Méténier G, Vivarès CP 2002. Fine analysis of the Pneumocystis carinii f. sp. carinii genome by twodimensional pulsed-field gel electrophoresis. Gene 293: 87-95.

Cushion MT 1998. Pneumocystis carinii. In L Collier, A Ballows, M Sussman, Topley and Wilson's microbiology and microbial infections, vol. IV, Medical mycology, L Ajello, R Hay, eds., 9th ed., Edward Arnold, London, p. 645-683.

Cushion MT 2004. Pneumocystis: unraveling the cloak of obscurity. Trends Microbiol 12: 243-229.

Cushion MT, Smulian AG, Slaven BE, Sesterhenn T, Arnold J, Staben C, Porollo A, Adamczak R, Meller J 2007. Transcriptome of Pneumocystis carinii during fulminate infection: carbohydrate metabolism and the concept of a compatible parasite. PLoS ONE 2: e423.

Dei-Cas E 2000. Pneumocystis infections: the iceberg? Med Mycol 38: $23-32$.

Dei-Cas E, Aliouat EM, Cailliez JC 2004. Cellular structure. In PD Walzer, MT Cushion, Pneumocystis pneumonia, 3rd ed., Marcel Dekker Inc, New York, p. 61-94.

Dei-Cas E, Chabé M, Moukhlis R, Durand-Joly I, Aliouat EM, Stringer JR, Cushion MT, Noel C, Sybren de Hoog G, Guillot J, Viscogliosi E 2006. Pneumocystis oryctolagi sp. nov., an uncultured fungus causing pneumonia in rabbits at weaning: review of current knowledge and description of a new taxon on genotypic, phylogenetic and phenotypic bases. FEMS Microbiol Rev 80: 853-871.

Dei-Cas E, Vernes A 1986. Parasitic adaptation of pathogenic fungi to the mammalian hosts. CRC Critical Rev Microbiol 13: 173-218.

Delanoë P, Delanoë M 1912. Sur les rapports des kystes de carinii du poumon des rats avec le Trypanosoma lewisi. CR Acad Sci (Paris) 155: 658-660.

Delaporte F 2003. A Doença de Chagas. História de uma calamidade continental, Holos Editora, Ribeirão Preto, 129 pp.

De Souza W, Benchimol M 2005. Basic biology of Pneumocystis carinii - A mini review. Mem Inst Oswaldo Cruz 100: 903-908.
De Stefano JA, Foy JM, Sullivan DW, Dawes SM, Cushion MT, Babcock GF, Sleight RG, van Halbeek H, Walzer PD 1994. Fractionation of developmental stages by counterflow centrifugal elutriation and sequential filtrations. Parasitol Res 80: 1-9.

De Stefano JA, Sleight RG, Babcock GF, Sramkoski RM, Walzer PD 1992. Isolation of Pneumocystis carinii cysts by flow cytometry. Parasitol Res 78: 179-182.

Doby JM, Kombila-Favry M 1978. Presence of sexual forms (cleistothecia and Hülle cells) in a case of human maxillary sinus aspergillosis caused by Aspergillus nidulans in association with Aspergillus fumigatus. Mycopathologia 64: 157-163.

Durkin MM, Shaw MM, Bartlett MS, Smith JW 1991. Culture and filtration methods for obtaining Pneumocystis carinii trophozoites and cysts. J Protozool (Suppl.) 38: 210S-212S.

Edman JC, Kovacs JA, Masur H, Santi DV, Elwood HJ, Sogin ML 1988. Ribosomal RNA sequence shows Pneumocystis carinii to be a member of the fungi. Nature 334: 519-522.

Eriksson OE 1994. Pneumocystis carinii, a parasite in lungs of mammals, referred to a new family and order (Pneumocystidaceae, Pneumocystidales, Ascomycota). Systema Ascomycetum 13: $165-180$.

Eriksson OE, Winka K 1997. Supraordinal taxa of the Ascomycota. Myconet 1: 1-16.

European Concerted Action on Pneumocystis carinii 1996. In vitro systems in Pneumocystis research. Parasitol Today 12: 245-249.

François F, Noël T, Pépin R, Brulfert A, Chastin C, Favel A, Villard J 2001. Alternative identification test relying upon sexual reproductive abilities of Candida lusitaniae strains isolated from hospitalized patients. J Clin Microbiol 39: 3906-3914.

Harigaya Y, Yamamoto M 2007. Molecular mechanisms underlying the mitosis-meiosis decision. Chromosome Res 15: 523-537.

Hughes WT 1982. Natural mode of acquisition for de novo infection with Pneumocystis carinii. J Infect Dis 145: 842-848.

Hughes WT 1987. Pneumocystis carinii Pneumonitis, Vol. I, CRC Press Inc, Boca Raton, 131 pp.

Itatani CA 1994. Ultrastructural demonstration of a pore in the cyst wall of Pneumocystis carinii. J Parasitol 80: 644-648.

Itatani CA 1996. Ultrastructural morphology of intermediate forms and forms suggestive of conjugation in the life cycle of Pneumocystis carinii. J Parasitol 82: 163-171.

Jirovec O 1964. Pneumocystis carinii, as the agent of interstitial plasma cell pneumonia in man. Bol Inst Pueric 21: 5-16.

Kim HK, Hughes WT, Feldman S 1972. Studies of morphology and immunofluorescence of Pneumocystis carinii. Proc Soc Exp Biol Med 141: 304-309.

Kottom TJ, Köhler JR, Thomas CF Jr, Fink GR, Limper AH 2003. Lung epithelial cells and extracellular matrix components induce expression of Pneumocystis carinii STE20, a gene complementing the mating and pseudohyphal growth defects of ste 20 mutant yeast. Infect Immun 71: 6463-6471.

Lautenschlager I, Lyytikainen O, Jokipii L, Jokipii A, Maiche A, Ruutu T, Tukiainen P, Ruutu P 1996. Immunodetection of Pneumocystis carinii in bronchoalveolar lavage specimens compared with methenamine silver stain. J Clin Microbiol 34: 728-730.

Lebron F, Vassallo R, Puri V, Limper AH 2003. Pneumocystis carinii cell wall beta-glucans initiate macrophage inflammatory responses through NF-kappaB activation. J Biol Chem 278: 25001-25008.

Li L, Wright SJ, Krystofova S, Park G, Borkovich KA 2007. Heterotrimeric $\mathrm{G}$ protein signaling in filamentous fungi. Annu Rev Microbiol 61: 423-452. 
Lim SK, Eveland WC, Porter RJ 1973. Development and evaluation of a direct fluorescent antibody method for the diagnosis of Pneumocystis carinii infections in experimental animals. Appl Microbiol 26: 666-671.

Martinez A, Aliouat EM, Pottier M, Gantois N, Pinçon C, Vitse-Standaert A, Dei-Cas E, Aliouat-Denis CM 2009. High-speed cell sorting of infectious trophic and cystic forms of Pneumocystis carinii. J Eukaryot Microbiol, in press.

Matsumoto Y, Yoshida Y 1984. Sporogony in Pneumocystis carinii: synaptonemal complexes and meiotic nuclear divisions observed in precysts. J Protozool 31: 420-428.

Mitchell RG, Chaplin AJ, Mackenzie DW 1987. Emericella nidulans in a maxillary sinus fungal mass. J Med Vet Mycol 25: 339-341.

Ng VL, Yajko DM, Hadley WK 1997. Extrapulmonary pneumocystosis. Clin Microbiol Rev 10: 401-418.

Nishida H, Sugiyama J 1994. Archiascomycetes: detection of a major new lineage within the Ascomycota. Mycoscience 35: 381-366.

O'Connell RJ, Panstruga R 2006. Tête-à-tête inside a plant cell: establishing compatibility between plants and biotrophic fungi and oomycetes. New Phytol 171: 699-718.

Palluault F, Pietrzyk B, Dei-Cas E, Slomianny C, Soulez B, Camus D 1991a. Three-dimensional reconstruction of rabbit-derived Pneumocystis carinii from serial-thin sections. I: Trophozoite. $J$ Protozool 38: 402-407.

Palluault F, Pietrzyk B, Dei-Cas E, Slomianny C, Soulez B, Camus D 1991b. Three-dimensional reconstruction of rabbit-derived Pneumocystis carinii from serial-thin sections. II: Intermediate precyst. J Protozool 38: 407-411.

Peters SE, English K, Rana A, Akter S, Malik S, Warburton NC, Duckett JG 2001. Synaptonemal complexes in the pre-cyst of Pneumocystis carinii. J Eukaryot Microbiol 48 (Suppl.): 134S.

Read JA, Burns SM 1991. A simple method of separation of Pneumocystis carinii from rat lung. Int J Exp Pathol 72: 673-677.

Redhead SA, Cushion MT, Frenkel JK, Stringer JR 2006. Pneumocystis and Trypanosoma cruzi: nomenclature and typifications. J Eukaryot Microbiol 53: 2-11.

Richardson JD, Queener SF, Bartlett M, Smith J 1989. Binary fission of Pneumocystis carinii trophozoites grown in vitro. J Protozool 36 (Suppl.): 27S-29S.

Ruffolo JJ 1994. Pneumocystis carinii cell structure. In PD Walzer, Pneumocystis carinii pneumonia, 2nd ed., Marcel Dekker Inc, New York, p. 25-43.

Schmatz DM, Powles M, McFadden DC, Pittarelli LA, Liberator PA, Anderson JW 1991. Treatment and prevention of Pneumocystis carinii pneumonia and further elucidation of the $P$. carinii life cycle with 1,3-beta-glucan synthesis inhibitor L-671,329. J Protozool 38 (Suppl.): 151S-153S.

Schmatz DM, Romancheck MA, Pittarelli LA, Schwartz RE, Fromtling RA, Nollstadt KH, Vanmiddlesworth FL, Wilson KE, Turner MJ 1990. Treatment of Pneumocystis carinii pneumonia with 1,3-beta-glucan synthesis inhibitors. Proc Natl Acad Sci USA 87: 5950-5954.

Sexton AC, Howlett BJ 2006. Parallels in fungal pathogenesis on plant and animal hosts. Eukaryot Cell 5: 1941-1949.

Smulian AG, Sesterhenn T, Tanaka R, Cushion MT 2001. The ste3 pheromone receptor gene of Pneumocystis carinii is surrounded by a cluster of signal transduction genes. Genetics 157: 991-1002.
Stringer JR, Cushion MT 1998. The genome of Pneumocystis carinii. FEMS Immunol Med Microbiol 22: 15-26.

Stringer SL, Stringer JR, Blase MA, Walzer PD, Cushion MT 1989. Pneumocystis carinii: sequence from ribosomal RNA implies a close relationship with fungi. Exp Parasitol 68: 450-461.

Sugiyama J, Hosaka K, Suh SO 2006. Early diverging Ascomycota: phylogenetic divergence and related evolutionary enigmas. $M y-$ cologia 98: 996-1005.

Sukura A, Ukkola T, Linder E, Lindberg LA 1994. Ultrastructural localization of monoclonal antibodies against Pneumocystis carinii. Differentiation between developmental stage and host origin. APMIS 102: 901-907.

Taylor MB, Easmon CS 1990. Separation of Pneumocystis carinii from the lung of the steroid-suppressed rat. FEMS Microbiol Lett 58: 49-53.

Thomas CF Jr, Kottom TJ, Leof EB, Limper AH 1998. Characterization of a mitogen-activated protein kinase from Pneumocystis carinii. Am J Physiol 275: L193-199.

Thomas CF Jr, Limper AH 2007. Current insights into the biology and pathogenesis of Pneumocystis pneumonia. Nat Rev Microbiol 5: 298-308.

Van der Meer MG, Brug SL 1942. Infection à Pneumocystis chez l'homme et chez les animaux. Ann Soc Belge Med Trop 22: 301.

Vavra J, Kucera K 1970. Pneumocystis carinii Delanoë, its ultrastructure and ultrastructural affinities. J Protozool 17: 463-483.

Vohra PK, Park JG, Sanyal B, Thomas CF Jr 2004. Expression analysis of PCSTE3, a putative pheromone receptor from the lung pathogenic fungus Pneumocystis carinii. Biochem Biophys Res Commun 319: 193-199.

Vohra PK, Puri V, Kottom TJ, Limper AH, Thomas CF Jr 2003a. Pneumocystis carinii STE11, an HMG-box protein, is phosphorylated by the mitogen activated protein kinase PCM. Gene 312: 173-179.

Vohra PK, Puri V, Thomas CF Jr 2003b. Complementation and characterization of the Pneumocystis carinii MAPK, PCM. FEBS Lett 551: 139-146.

Vossen MEMH, Beckers PJA, Meuwissen JHET, Stadhouders AM 1978. Developmental biology of Pneumocystis carinii: an alternative view on the life cycle of the parasite. $Z$ Parazitenkd 55: 101-118.

Wakefield AE 1996. DNA sequences identical to Pneumocystis carinii f. sp. carinii and Pneumocystis carinii f. sp. hominis in samples of air spora. J Clin Microbiol 34: 1754-1759.

Walzer PD, Schnelle V, Armstrong D, Rosen PP 1977. Nude mouse: a new experimental model for Pneumocystis carinii infection. Science 197: 177-179.

Wyder MA, Rasch EM, Kaneshiro ES 1998. Quantitation of absolute Pneumocystis carinii nuclear DNA content. Trophic and cystic forms isolated from infected rat lungs are haploid organisms. J Eukaryot Microbiol 45: 233-239.

Yoshida Y 1989. Ultrastructural studies of Pneumocystis carinii. J Protozool 36: 53-60.

Yoshida Y, Matsumoto Y, Yamada M, Okabayashi K, Yoshikawa H, Nakazawa M 1984. Pneumocystis carinii: electron microscopic investigation on the interaction of trophozoite and alveolar lining cell. Zentralbl Bakteriol Mikrobiol Hyg [A] 256: 390-399. 